\title{
INDUSTRIAL RELATIONS AS NEWS
}

\author{
- John Cordery, Bruce Jamieson and Barrie Stacey
}

\section{ABSTRACT}

During 1976 a study of the treatment of industrial relations by four New Zealand metropolitan newspapers was carried out at Massey University. In 1977 a larger study dealing with the treatment of industrial relations by television, radio and eight major newspapers was carried out at Canterbury University. In this article the authors examine the news coverage of industrial relations by the mass media taking account not only of the New Zealand but also of the American and British research findings.

\section{INTRODUCTION}

We take for granted a way of life where we can perceive regional, national and world events presented by the mass communication media of television, radio and newspapers, which in the case of television apparently little distorts the reality that is being reported. At times it gives us a feeling of direct observation or even vicarious participation. The mass media cultivate large socially varied audiences and help define the fluctuating agenda of public discourse, hence provide a common bond among all social groups and classes in the country. Industrial or employer-employee relations is a topic of news which the media keep in front of their audiences, often as a matter of public concern. In the months up to the 1978 general election we shall inevitablv be told on many occasions that 1977 was a bad year for strikes and the worst year for strikes since the waterfront strike (not lock-out) year of 1951. For most people the mass media constitute the prime sources of information about events in the world. An analysis of industrial relations news coverage by the mass media will tell us much about the quality of the information they present and the use of industrial relations as news.

\section{AMOUNT OF COVERAGE}

Industrial relations is regarded by news editors and media professionals as a permanently newsworthy topic. Metropolitan newspapers devote around two per cent of their total non-advertising contents to this

\footnotetext{
- John Cordery is temporary Lecturer in Industrial Law at Massey University, Bruce Jamieson is Reader in Psychology and Barrie Stacey Senior Lecturer in Psychology at Canterbury University.
}

type of news, television programmes around five per cent, and radio news programmes around nine per cent (more in the evening than the morning). Newspapers print many letters from readers on industrial relations, often featuring them prominently. Industrial relations is a popular topic for editorials, particularly those of the public concern or moralising type. However, there is a lack of in-depth feature writing on the topic. In May 1976, among a sample of four New Zealand newspapers (Christchurch Star, Evening Post, New Zealand Herald and Otago Daily Times), a daily coverage of 212 column inches of items on industrial relations was published - that is more than a page of news over the four. Even the most casual of readers or viewers or listeners is likely to encounter at least some industrial relations news on any given day.

\section{SUBJECT MATTER}

The main focus of industrial relations news is remarkably similar for all papers and programmes. It is upon a category of events usually termed "industrial action," that is strikes, go-slows, work-to-rules, and other forms of overt or threatened action. In the May 1976 sample of New Zealand papers just referred to, 56 per cent of all news items fell into the industrial action category. This figure is undoubtedly too high for all the media over the course of a whole year. But a pronounced feature of the use of industrial relations as news is the prominence given to industrial action, especially strikes. There seem to be only three other categories of events, where industrial action is not taking place or threatened, which are regularly featured as news - the statements and actions of 
trade unionists, the statements and actions of politicians, and employer-employee negotiations. The economic context of industrial relations is neglected in the news. Employers and employer organizations are not featured to the extent that trade unionists and trade unions are. The mass media ignore the bulk of ongoing industrial relations activity. The recurring criticism of the mass media, that they present news which is biased towards conflict, disruption, threat, disaster, abnormality and deviancy, appears largely valid with reference to industrial relations. So does the common complaint of trade unionists that the public is presented by the media with a faise image of union activity.

All media present news, including industrial relations news, to their audiences as an accurate or near accurate account of social reality. The selective and constructive features of industrial relations news production are not widely appreciated. Because the media adopt a fairly uniform approach to their coverage of industrial relations and make use of a common news source, the New Zealand Press Association, their presentation of news as social reality is probably rendered more convincing. It appears that many people accept the industrial relations news they come into contact with as an accurate account of industrial relations in the country.

News bulletins and items are inevitably timebound. The news has to be produced by the media every day. This means that events which can be conveniently processed within the recurring 24-hour cycle are much more likely to become news than events which unfold slowly or at an awkward pace. Thus a statement by a Minister on, for instance, the low level of strikes in Danish fish-canning factories by comparison with New Zealand fish-canning factories can be fitted into the news more easily than, for instance, medical information about the pattern of deterioration in health among long-term employees in a factory producing a synthetic product. The ambiguities or complexities of certain events make them difficult to use by newspeople given their mode of operation and their views about what is newsworthy

The incessant pressures on newspeople are partly reduced by the regular covering of pre-scheduled events, that is events announced in advance by their conveners.
In practice this means a good deal of reliance is placed on official announcements, political speeches, statements by prominent figures, and exchanges between politicians and trade unionists. For example, if it were made known that a Minister was going to speak at a function on, say, the disruptive influence of foreign stirrers on the fishermen of Flordland, media professionals could cover it with the certainty of an easy news item and one that could be presented as a public issue, with also the possibility of an emotive headline such as "Red menace in the Fiords." The fact that politicians are anxious to attract public support for their policies makes it worth their while to obtain media coverage of their activities (though they by no means like some of the coverage they get). At times the same consideration applies to employers and trade unions, including employer associations and the $\mathrm{FOL}$.

In several studies investigators have examined the details of the media's presentation of industrial relations news. Inevitably, industrial action features prominently in these examinations. It seems that strikes in some sectors of the economy are routinely publicised, in other sectors largely ignored. Distinctions between official and unoflioial strikes, and between strikes and lock-outs, are not consistently made. Lockouts are often described as strikes. When casual explanations for disputes are given in the news, they are typically superficial, often involving 'more money' and/or something trifling. The Massey and Canterbury studies in New Zealand indicate that rumour-mongering about industrial action is a prominent feature of our industrial relations news. To illustrate this, suppose there were a national meeting of the N.Z.E.I. or P.P.T.A, and a delegate says that $s /$ he feels if certain objectives were not achieved in the next 6 to 12 months then action to achieve them should be considered, this would probably generate a headline such as "Teachers threaten action." The FOL conference, where a good number of proposals are tossed about, is a rich source of rumours. Many of the participants in industrial relations are familiar with the danger of saying something which might be presented in the media as a dramatic or sensational utterance. Not infrequently. individuals and organisations make it known that they feel they have recelved 
unfair or biased treatment in the media.

On average, when they occur, one cause or one effect are given per item of industrial relations news in the media. Across the field of industrial relations, dissatisfaction with pay, dissatisfaction with working conditions and opposition to employer (including government as an employer) policy are the most frequently stated causes of industrial action: general or nonspecific disruption is the most frequently stated effect, followed (far less frequently) by inconvenience to customers/public and by some specific loss or disruption of efficiency. But lack of attention to causes and effects is a more significant feature of industrial relations news than treatment of causes and effects. Yet in these circumstances, statements about the supposed influence of "pommie stirrers," "commos," "agitators" and the "militant minority" are routinely reported, presumably as newsworthy 'analyses' of industrial action. Newspaper editorials are almost always hostile to industrial action by trade unionists. The media, then, tend to simplify greatly the events they cover, to provide little reliable background information, and to pay little attention to the complex of causes and effects in industrial relations. Taken together, these tendencies contribute to the trivialization of industrial relations events as news.

Cliches, stereotypes, crude images, blackand-white issues, and generalised characterizations of industrial conflict are commonplace in the news. Much is made of the notion of a unique 'National Interest' which is somehow divorced or different from the people who actually live in the nation. It is an abstract diffuse notion by which the media attempt to lead people to see the interests of particular groups as the interests of the whole nation. Trade unions are often presented as the active and (ir) responsible agents in disputes, their decisions and actions being treated as the reason for the existence of the disputes. Strikes are typically regarded as a matter for lament, regret or hostility, and very rarely dealt with from the point of view of the striker. Much more attention is given to trade unions in terms of whether their activities are right or wrong, than in terms of whether their activities are efficacious or not. And employees are presented as being morally wrong much more often than they are presented as being morally right. In addition, there is a tendency on the part of the media to present the person who makes a great deal of money or large profits with a company as a benefactor of the nation, and hence as an outstandingly good citizen. The difference is illustrated in the following observation on The Times' approach to industrial relations in Britain:

'Holding up to public blackmail.' This is what the postmen were doing, according to The Times when they demanded an increase on a basic wage of $\Sigma 11$ 10s od (about \$21) a week. This is what the dockers were doing when they announced that they would prefer to have their weekends off, like everybody else. This, of course, is what the seamen were doing when they demanded overtime pay for anything over and above a forty-hour week. And on the day when The Times was robuking the postmen for exhausting its patience an article appeared on the same page which made a spirited defence of land speculators. It seemed that these enterprising men were not 'holding up the public to blackmail' but simply taking legitimate risks and making legitimate profits. 1

Little wonder some analysts have concluded that public opinion on industrial relations, especially strikes, is a social delusion.

\section{PARTICIPANTS AND SPOKESPERSONS}

It is clear from studies of the media that the participants featured in industrial relations news are most frequently from the work-force and its organisations, rather than from government, employers, management, state bodies involved in industrial relations, or the general public. The 1977 Canterbury study of New Zealand media indicates that participants from labour are featured in about 3 out of 4 news items (4 out of 5 on television), from government in about half of news items, from employers in about 1 out of 3 items, from state bodies in about 1 out of 4 items, and from the public in less than 1 out of 10 items. It also indicates that participants from labour are featured more prominently than in this general pattern: (1) in newspaper headlines;

1-P. Toynbee. 'The language of inequality,' in Blackburn and Cockbum (eds.). The Incompartibles: Trade Union Militancy and the Consensus. Penguin, 1967. 
(2) as a source of quotations; (3) as spokespersons: (4) as the basis of a news item: and (5) as interviewees. However, government participants may be featured as frequently as labour participants on those occasions when government involves itself greatly in industrial relations. What emerges from the Canterbury and other studies is the prominence which the media give to labour people, the secondary extent to which government members are featured by newspeople, and the relatively infrequent use of participants from the employer's side in the news. The prominence given to labour people probably reinforces the impression that industrial relations events are largely the result of the actions of employees and unions.

Researchers in Britain have found that there is a difference both in the frequencies with which the news media characterise (and report characterisations of) participants by the use of adjectives, and in the types of adjective applied. Participants from labour are most frequently characterised, and usually in a negative way, e.g. as angry, divided, militant. In New Zealand the media characterise participants far less frequently than is the case in Britain. It appears that here, participants are characterised in about 1 out of 7 or 8 news items. with labour people being characterised in a slightly larger minority of items. There does not seem to be any clear pattern in the way different types of participants are characterised in news presentation, with the exception of a somewhat positive characterisation of government participants. The related words - concerned, disturbed. troubled, unhappy and worried - are relatively popular as adjectives for characterisation of participants, as are the words militant, firm/steadfast/united, hopeful/ optimistic, divided/fragmented/split, and dissatisfied/restless/disappointed.

Where employees are in conflict with a private employer the issue is less likely to be widely publicized by the media than if a similar situation arises in the public sector, for in this latter case the government is more directly involved. Government involvement changes the news potential of a conflict for several reasons. The government has more power and a wider scope for action than a private employer, and its electoral support gives it a particular type of legitimacy the private employer lacks. The government can threaten its own public employees with more severe penalties than can a private employer by invoking both roles - as employer and as the government, e.g. use of the Public Safety Act, or the deregistration of a union, or the use of armed services personnel as substitute labour. Further, a government is always able to promise change or new legislation, which may well be newsworthy. It is likely that government statements and/ or actions will cause controversy, and possibly become good news. The government can easily shift from its employer role by declaring it must give priority to the 'country' or the 'national interest,' and publicly face its employees with these abstractions while really confronting them with other priorities and interests. When the 'national interest' is credibly involved, it provides the mass media with an opportunity to become parties to the conflict. Probably one of the best known examples $\mathrm{BBC}$ in Britain during the highly important year of 1926. The BBC chief John (later Lord) Reith said after the 1926 genera! strike: ". ... since the BBC was a national institution, and since the Government in this crisis was acting for the people, the BBC was for the Government in the crisis too.... The only definite complaint may be that we had no definite speaker from the labour side. We asked to be allowed to do so, but the decision eventually was that since the strike had been declared illegal this could not be allowed."2 So much for the balanced impartial presentation of news. Finally, government in the modern nation indulges in "news management" and the functionaries of government use newspeople, sometimes willingly, sometimes unwillingly, to this end.

\section{EXPLANATIONS OF COVERAGE AND CONTENT}

There have been a number of attempts to explain the manner in which industrial relations are presented as news, especially the media's emphasis on conflict, economic disruption and trade unions. One attempted explanation emphasizes the social visibility of disputes and strikes, and their significance as a source of economic loss. Much of industrial relations, it is argued, are

2-A. Brigos, Hiatory of Brosdcasting in the U.K. Vol. 1, Oxford, 1961 
quiet and unseen, whereas conflict and strikes are collective phenomena which thrust themselves to the surface of society. Trade unions and their members are likely to be highly publicised in the news because of their relationship to events that are socially disruptive, overt, and even at times spectacular (e.g. mass marches, demonstrations, pickets).

This explanation is far from convincing. Some disputes undoubtedly have a social visibility where they are located and/or make an impact, but many disputes and strikes are not overt in the sense of being overtly visible to the public. The social visibility of conflict and strikes relates largely to what newspeople are looking for and wishing to bring to the attention of the public by the media of communication. In addition, the financial costs of disputes are exaggerated in the media, as in some other places. In New Zealand, accidents, illness and alcoholism are all more important sources of economic loss than disputes, and all have worse general consequences. It has been estimated, for example, that for every $\$ 1 \mathrm{M}$ lost in disputes some $\$ 4 \mathrm{M}$ to $\$ 5 \mathrm{M}$ are lost as the result of alcohol abuse. There is nothing about a hospital which makes it less visible than a factory or office block, or transport depot or building site. The media heavily exploit medical/ hospital themes away from industrial relations. Occupational accidents occur constantly and could easily be fitted into the cycle of news production. Consider the headlines of two possible news items: "M.P. has harsh words for freezing works' unions at Landowners' meeting" and "After accident meat company fined for permitting unguarded machines." Torrents of harsh, stern and threatening words are directed at the freezing works' unions, and a few hundred more from an M.P. could only have miniscule if any significance. The fact that a company puts its employees at risk would appear to have more than miniscule significance. Which item, however, is likely to be publicised by newspeople?

A second attempted explanation is based upon the argument that industrial relations events involving conflict, disruption and strikes are prominent in the news because media professionals regard them as highly newsworthy. Having a high news value means that they attract an audience and retain its interest, and, relatedly, they facilitate audience comprehension of the events and the personalities involved. Reports of conflict, disruption and strikes, it is argued, enable people to utilize a range of stock notions and stereotypes about such events, and about conflict in general. Associated with this is the operation of journalistic beliefs about 'bad news being the good news.' Concentrating the attention of the public on conflict, economic disruption and trade unions, and fostering beliefs that the incidence of strikes is excessive, costly and unnecessary, always allows newspeople to interpret the news as a cause for public concern and indicative of the need for something to be done.

A third attempted explanation has a number of variants. All involve the idea that industrial relations news production is shaped within the media by an interpretive framework based upon particular ways of perceiving society, its institutions and values. Such an interpretive framework arises largely from the political and economic circumstances in which the media and their newspeople operate (and are a part of). It involves acceptance of concepts, ideas, practices and values with conservative biases which support the economic and industrial status quo. Stuart Hood, a writer, journalist and former editor of BBC news, describes the situation at the BBC as an "expression of a middleclass consensus politics which continue a tradition of impartiality on the side of the establishment." 3 Sociologist Stanley Cohen, in a review of television news research in New Society ( 9 September 1976), concludes: "Buried in the apparent diversity of television news is a hidden consensus about trade unions, strikes, inflation - located in the political culture itself. Contradictory evidence is ignored or smothered to produce an inferential structure, a consensual view of society which, at its most damaging, includes laying the blame for industrial relations at the door of the workforce." Others would argue that the media present industrial relations news within a framework largely predefined by powerful elites, particularly owners of the media, largescale advertisers and government. While diversity and variation, with a plurality of views, is permitted in news presentation, it takes place within limits set by political 
and economic imperatives originating in the centres of power the media represent. works more of such interpretative frameindustriat riains the social one-sidedness of critical relations news, its continuous its emphasis of employees and unions, its exaggeration conflict and strikes, and

\section{INDUSTRIAL RELATIONS AS NEWS}

Research in New Zealand and abroad shows that any faith in the impartiality. neutrality, balance of representativeness of industrial relations news produced by the mass media, is misplaced. This is particularly important with regard to television, for a majority of the population apparently believes it is a trustworthy news medium For most people, newspapers lack the credibility of television.

Newspeople in all the media select some events and ignore others, give precedence to some people and organizations and not to others, demarcate contexts for industrial relations events, and state or imply what is 'normal' or 'acceptable.' They have a predilection for industrial action, particularly strikes, which they present largely in negative terms. Alleged facts are often presented without adequate background information, but within a frame of reference or an inter- pretive framework stemming from assumptions about society and its organizations. In the industrial relations area of news, the sources of tacts tend to be government and employers, which partly accounts for the relatively low level of overt coverage employers and their organizations receive in the news. Labour is utilized for action and events, or possible action and events. Industrial relations is presented as being mainly the outcome of actions by employees and unions. Government involvement in a dispute increases its news potential and, therefore, increases its likelihood of being widely publicised. The media are in a position often to define the important events of the day or week and, also. to generate issues of 'public concern' which enable them credibly to call for government action. Journalistic beliefs about the news value of events are ever present and at times influ-
ential.

News is not a reflection of reality, of the industrial relations in the world outside the media. It is the deliberately manufactured product of people chosen by their employers to do this selective, judgmental and creative work within limits of time, molatioy and other pressures. It bears a relationship to reality of the order that reality of fish swimming in the bear to the 